\title{
異なる角度の越流型水制周辺流れの \\ 二次元数值解析 \\ 2-D NUMERICAL ANALYSIS OF FLOW \\ AROUND SUBMERSIBLE GROIN FOR DIFFERENT GROIN ANGLE
}

\author{
川口広司 $1 \cdot$ 渡辺明英 $2 \cdot$ 福岡捷二 3 \\ Hiroshi KAWAGUCHI, Akihide WATANABE and Shoji FUKUOKA
}

\author{
1学生会員 工修 広島大学大学院 環境工学専攻 博士課程後期（テ739-8527 東広島市鏡山1-4-1） \\ 2 正会員 工博 広島大学助教授 工学部第4類(建設系) 地域環境工学講座（同上） \\ 3 フェロー会員 Ph.D 工博 広島大学教授 工学部第4類(建設系) 地域環境工学講座（同上）
}

\begin{abstract}
Groin is expected to be used for various purposes. For each purpose, groin arrangement has been studied comprehensively through observations, experiments and numerical analyses. Flow around a groin has 3-D characteristic. For practical applications, a quasi-3-D numerical model is developed with introduction of hydrodynamic force on groin to predict flow and bed topography. The hydrodynamic force is introduced theoretically by volume integration of Fuler equation.

2-D numerical analysis is not effective very much for 3-D flow around a groin. But the 2-D using hydrodynamic force on groin and boundary condition of periodicity is effective in respect of workload. The 2-D numerical model is considered to be able to predict reduction of velocity due to presence of groins. In this paper, we discuss characteristics of experimental flow separation. Pressure fields around the submersible groins for different groin angles from experiment is compared with the 2-D numerical analysis having static pressure distribution. It also describes about capability and scope of application of the 2-D numerical analysis.
\end{abstract}

Key Words : submersible groin, groin angle, hydrodynamic force, 2-D numerical analysis, pressure fields

\section{1. 序論}

水制には多様な役割が期待されており，それぞれの目 的に応じた現地観測や模型実験, 数値解析による配置法 の検討が行われてきた ${ }^{1) \sim 5)}$. 水制周辺は3次元流れとなる が，実河川への適用を考え，水制による流体力を導入し

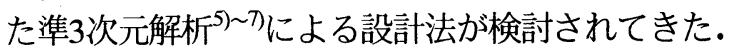

水制に関する解析には次のような研究があげられる. 福岡・渡辺は, ベーン工に作用する流体力を運動方程式 の体積積分から理論的に取り込み，ベーン工を設置した 河道における流れと河床変動を高い精度で再現した ${ }^{8)}$. 福岡·西村らは，不透過水制周辺の流れの準3次元解析に おいて，基礎方程式に流体力を導入することによって水 制周辺の流れ及び河床変動の実験及び現地デー夕の特徵

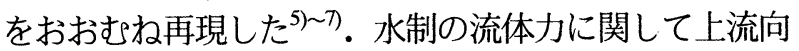
き，直角，下流向きの越流型不透過水制に作用する流体 力が直接測定され, 抗力・揚力係数の值が明らかにされ
てきた ${ }^{9)}$. 福岡・渡辺らは周期境界条件を用いて透過水制 周辺の流れの3次元解析を行い，水制周辺の流れの特徵 を概ね再現した ${ }^{10)}$. 河原らはk- $\varepsilon$ モデルを用いた不透過 水制周辺の流れの3次元解析を行い，水制の水はね効果 や水制背後の剥離流れなど，水制周辺の3次元流れを検 討している ${ }^{11)}$.

水制周辺の3次元性の強い流れの詳細を2次元解析で再 現することは困難である. しかし，水制域での流速の低 減や水はね効果などは2次元解析でも表現ができると考 えられる.周期境界条件を用いた水制周辺の流れの2次 元解析は計算量が比較的少なく, 実用上も有効な手段と なり得る。

本研究は, 周期境界条件, 圧力に静水圧分布を仮定し, 流体力を導入した連続越流型水制周辺の流れの2次元解 析を行い，静水圧を仮定した計算結果と実験結果を比較 している.これにより，流れに対する角度が異なる水制 背後の剥離流れと圧力場を検討し，2次元解析の適用性 とその限界を示すことを目的とする。 


\section{2. 越流型水制周辺の流れの2次元解析}

解析の対象は著者らによる き越流不透過水制を有する固定床流れ(表-1)の実験であ り，水制によって同様な流れ場が形成されている平衡区 間である。

\section{（1）流れの基礎方程式}

解析には定常な自由水面のある流れ場に渦度-流関数 法を適用する，x軸は流下方向，y軸は横断方向，z軸は $\mathrm{x}$-y面に鉛直な軸とする. 圧力を静水圧分布で仮定した 水深平均の運動方程式は次の式(1)で表される. 水制によ る外力は水制に作用する単位体積あたりの流体力 $\vec{F}$ を用 いて運動方程式に導入される。

$$
\begin{aligned}
\frac{\partial \vec{v}}{\partial t}+(\vec{v} \cdot \nabla) & =\vec{X}-g \nabla \xi+\varepsilon \nabla^{2} \vec{v}-\frac{\vec{\tau}_{b}}{\rho h}-\frac{1}{h} \int \frac{\vec{F}}{\rho} d z \\
\check{E} & \quad \vec{X}=(g \sin \theta, 0), \quad \vec{\tau}_{b}=\frac{\rho g n^{2}}{h^{1 / 3}} \sqrt{u^{2}+v^{2}} \cdot \vec{v} \\
\varepsilon & =\alpha \Delta U l+\frac{\kappa}{6} u . h \\
\kappa & =0.4, \alpha=0.006, u_{*}=\sqrt{g R I_{e}}
\end{aligned}
$$

である. $\theta$ はz軸の鉛直軸からの角度であり, $\cos \theta \doteqdot 1 と$ する. 河床せん断力 $\vec{\tau}_{b}$ は実験の Manning粗度係数 $n(=0.021)$ を用いて求める. 渦動粘性係数は, 崇田・清水 の式 ${ }^{12}(2)$ に実験值を使って概算した值 $\left(\varepsilon=8.42 \mathrm{~cm}^{2} / \mathrm{s}\right)$ を用 いた。ここで，l水制長， $\Delta U$ は実験の最大，最小流速 の差である.

水深平均した運動方程式(1)のRotationとDivergenceをと り, 渦度方程式(3), 圧力方程式(4)を導く. 圧力方程式 ではZ軸上の水位 $\xi$ を解くことになる。

〈渦度方程式〉

$$
\begin{aligned}
& \frac{\partial \omega_{z}}{\partial t}+\frac{\partial}{\partial x}\left(u \omega_{z}\right)+\frac{\partial}{\partial y}\left(v \omega_{z}\right)=\varepsilon \frac{\partial^{2} \omega_{z}}{\partial x^{2}}+\varepsilon \frac{\partial^{2} \omega_{z}}{\partial y^{2}} \\
& -\frac{\partial}{\partial x}\left(\frac{\tau_{b y}}{\rho h}\right)+\frac{\partial}{\partial y}\left(\frac{\tau_{b x}}{\rho h}\right)-\frac{\partial}{\partial x}\left[\frac{1}{h} \int\left(\frac{F_{y}}{\rho}\right) d z\right]+\frac{\partial}{\partial y}\left[\frac{1}{h} \int\left(\frac{F_{x}}{\rho}\right) d z\right]
\end{aligned}
$$

\section{〈圧力方程式〉}

$$
\begin{aligned}
& g\left(\frac{\partial^{2} \xi}{\partial x^{2}}+\frac{\partial^{2} \xi}{\partial y^{2}}\right)=-\left(\frac{\partial u}{\partial x}\right)^{2}-\left(\frac{\partial u}{\partial y}\right)\left(\frac{\partial v}{\partial x}\right)-\left(\frac{\partial v}{\partial y}\right)^{2} \\
& -u \frac{\partial D}{\partial x}-v \frac{\partial D}{\partial y}+\varepsilon \frac{\partial^{2} D}{\partial x^{2}}+\varepsilon \frac{\partial^{2} D}{\partial y^{2}}-\frac{\partial}{\partial x}\left(\frac{\tau_{b x}}{\rho h}\right)-\frac{\partial}{\partial y}\left(\frac{\tau_{b y}}{\rho h}\right) \\
& -\frac{\partial}{\partial x}\left[\frac{1}{h} \int\left(\frac{F_{x}}{\rho}\right) d z\right]-\frac{\partial}{\partial y}\left[\frac{1}{h} \int\left(\frac{F_{y}}{\rho}\right) d z\right]
\end{aligned}
$$

表-1 解析対象の実験諸元

\begin{tabular}{|c|c|}
\hline 流量 $\mathrm{Q}(\mathrm{l} / \mathrm{s})$ & 30.67 \\
\hline 平均水深 $h(\mathrm{~cm})$ & 6 \\
\hline 水路床勾配 $i$ & $1 / 500$ \\
\hline 水制長 $l(\mathrm{~cm})$ & 50 \\
\hline 水制幅 $b(\mathrm{~cm})$ & 5 \\
\hline 水制高 $h_{g}(\mathrm{~cm})$ & 3 \\
\hline 水制間隔 $s(\mathrm{~m})$ & 1.0 \\
\hline 水制閣隔水制長 $s / l$ & 2 \\
\hline 水制角度 $\theta\left({ }^{\circ}\right)$ & $75,90,105$ \\
\hline
\end{tabular}

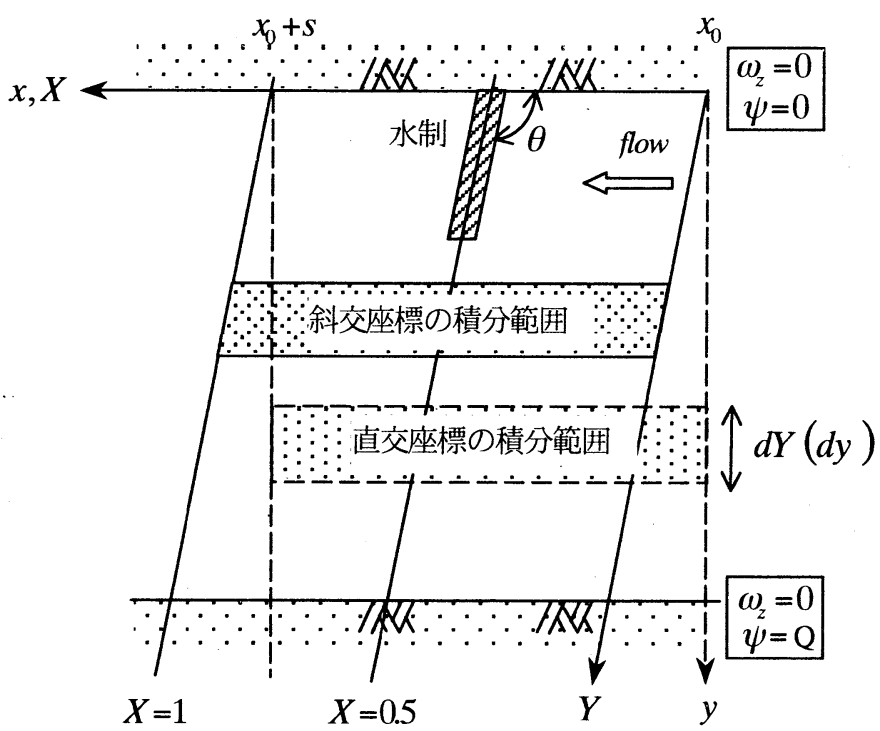

図-1＼cjkstart斜交座標の積分範囲

ここで, $\quad \omega_{z}=\frac{\partial v}{\partial x}-\frac{\partial u}{\partial y} \quad D=\frac{\partial u}{\partial x}+\frac{\partial v}{\partial y}$

である．時間前進で収束計算し，定常解を得るために， 渦度方程式には非定常項を残す。

水深積分した定常な連続式により流関数 $\psi$ を定義し, 渦度 $\omega_{z}$ と流関数 $\psi$ の関係式(5)を導く.

〈流関数-渦度関係式〉

$-\omega_{z}=-\frac{\partial v}{\partial x}+\frac{\partial u}{\partial y}=\frac{\partial}{\partial x}\left(\frac{1}{h} \frac{\partial \psi}{\partial x}\right)+\frac{\partial}{\partial y}\left(\frac{1}{h} \frac{\partial \psi}{\partial y}\right)$

境界条件は, y方向に渦度 $\omega_{z}=0$, 水位勾配 $\frac{\partial \xi}{\partial x}=0$ のスリップ条件, 流関数は $\psi_{\text {y max }}=\mathrm{Q}, \psi_{0}=0$ とした. x方向には全て周期境界条件を用いた。水位の境界条件 はNeumann条件としたため, 水位は平均水位を与えて定 常解を求めた。

\section{（2）解析方法}

基礎方程式の渦度方程式(3), 圧力方程式(4), 流関数渦度関係式(5)はx方向，y方向に積分され，以下のように $\mathrm{x}$ 方向はGalerkin法により, y方向は差分法により離散化 


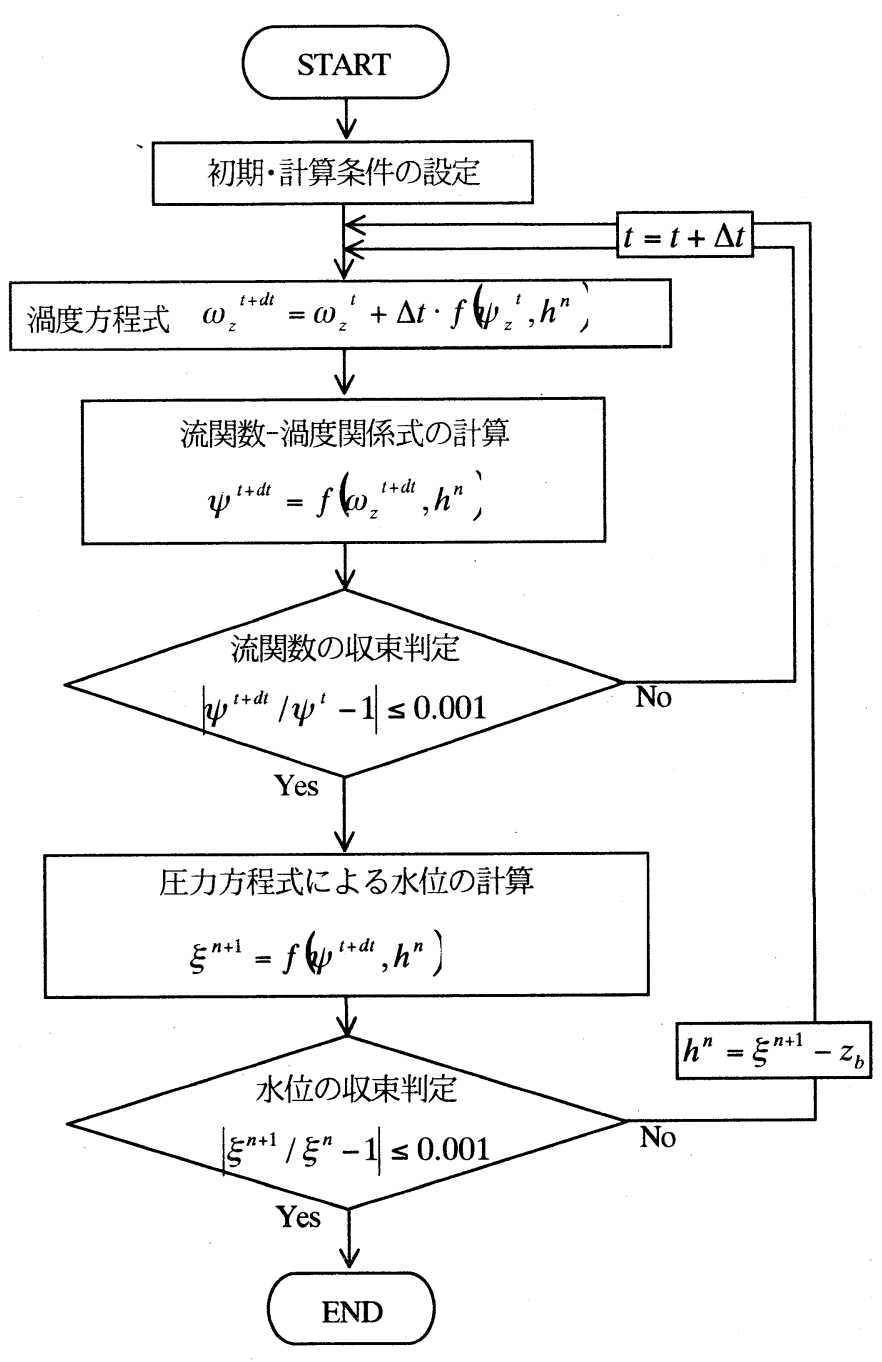

図-2＼cjkstart計算フローチャート

される.

図-1に示すように, $\mathrm{x}$ 方向は流下方向の任意の座標 $x_{0}$ から水制間隔 $s$ 離れた $x_{0}+s$ まで, $y$ 方向は横断方向の任意 の座標 $\mathrm{y}$ から $\mathrm{dy}(=5 \mathrm{~cm})$ 離れた $\mathrm{y}+\mathrm{dy}$ まで積分する．渦度方 程式(3), 圧力方程式(4), 流関数-渦度関係式(5)の $\mathrm{x}$ 方向 についてGalerkin法による離散化を行う，上流向き，下 流向き水制の計算を考慮して，積分した基礎方程式を式 (6)により直交座標 $(x, y)$ から流下方向と水制の長さ方向を 軸とする斜交座標 $(\mathrm{X}, \mathrm{Y})$ に変換する．離散化すべき基礎 方程式の各項 $f$ は次式(7)のようになる。ここで, Jは Jacobianである。

$$
\begin{aligned}
\left(\begin{array}{l}
X \\
Y
\end{array}\right) & =\left(\begin{array}{cc}
1 / s & -1 / s \tan \theta \\
0 & 1
\end{array}\right)\left(\begin{array}{l}
x \\
y
\end{array}\right) \\
\int_{y}^{y+d y} \int_{x_{0}}^{x_{0}+s} f(x, y) d x d y & =\int_{Y}^{y+a r} \int_{0}^{1} f(X, Y) J(X, Y) d X d Y \\
& =s \int_{Y}^{Y+d Y} \int_{0}^{1} f(X, Y) d X d Y
\end{aligned}
$$

Galerkin法により離散化する.

$f(X, Y)=f_{0}(Y)+\sum_{k=1}^{10}\left[f_{s k}(Y) \sin (2 \pi k X)+f_{c k}(Y) \cos (2 \pi k X)\right]$ ただし，せん断力項は最小波長を10分割した大きさで数 値積分して離散化する。

$\mathrm{y}$ 方向はdy=5cmで差分法により離散化する．渦度 $\omega_{z}$, 流関数 $\psi$ と水位 $\xi$, 河床高 $z_{b}$ は交互に配置する.

図-2は計算のフローチャートを示している. ある水深 に対して，渦度方程式をEulerの陽解法を用いて計算を行 い，対応する流関数の収束計算を行う. 流関数の結果が 前のtime stepと比較して䛊差0.1\%を満たすまで反復計算 を行う. 求めた流速に対する水位を圧力方程式により求 める. 前回の水位と比較して誤差 $0.1 \% を$ 満たすまで反復 計算を行い，水制周辺の流れの2次元定常解を得る.

\section{（3）流体力}

単位体積あたりの抗力 $F_{X}$, 揚力 $F_{Y}$ のX方向分布は水 制に作用する抗力 $F_{D}$, 揚力 $F_{L}$ とHeaviside関数 $H(X)$ を用 いて式(8)のように表される.

$$
\begin{array}{r}
\vec{F}=\left(F_{X}, F_{y}\right)=\left(\frac{F_{D}}{h_{g} b l} P(X), \frac{F_{L}}{h_{g} b l} P(X)\right) \\
P(X)=H(X-0.5+b / 2 s)-H(X-0.5-b / 2 s) \\
\text { ここで, } \quad F_{D}=C_{D} h_{g} l \frac{\rho u|u|}{2}, F_{L}=C_{L} h_{g} l \frac{\rho u|u|}{2}
\end{array}
$$

である. $h_{g}$ は水制高, lは水制長，bは水制幅，sは水制間 隔, $u$ は各横断方向メッシュ内の水制上流 $5 \mathrm{~cm}$ での接近 流速である. 著者らの研究" より抗力係数 $C_{D}$ は5.6, 揚 力係数 $C_{L}$ は, 上流向き, 直角, 下流向き水制の順に-1.6, 0.2，1.6とした. 計測した流体力から求めた抗力・揚力係 数は水制全体の平均值であるが, 計算の抗力・揚力係数 は横断方向に一様に分布させた。

\section{3. 解析結果と実験結果の比較検討}

水制周辺の流れを 2 次元的に取り扱うと問題となるの は水制背後の剥離流れに伴う圧力分布である. 水制背後 の流れは，水制先端から水制域へ流れ込むことによる平 面的な剥離流れと，水制上を越流する流れによる鉛直面 内の剥離流れが混在した流れからなる.このため, 水制 背後の圧力は静水圧より低くなる. 以下に, 主流に対し て直角, 上流向き, 下流向き水制の水位, 主流速, 横断 流速, 水制背後の剥離流れと圧力低下に関する考察を行 い，2次元解析の適用性とその限界を検討する.

$\mathrm{x}$ 方向は次のような10次までのFourier級数展開を行い, 


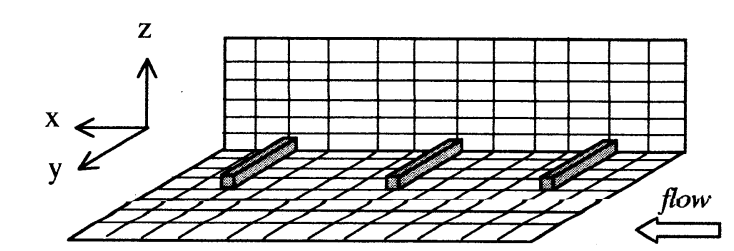

口水制設置位置 o exp. - cal.

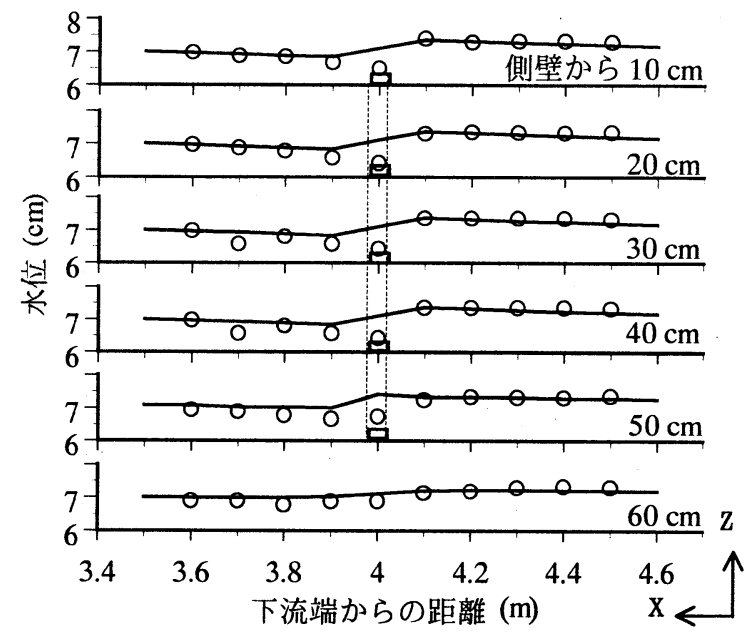

図-3-a 直角水制周辺の水位分布の縱断変化

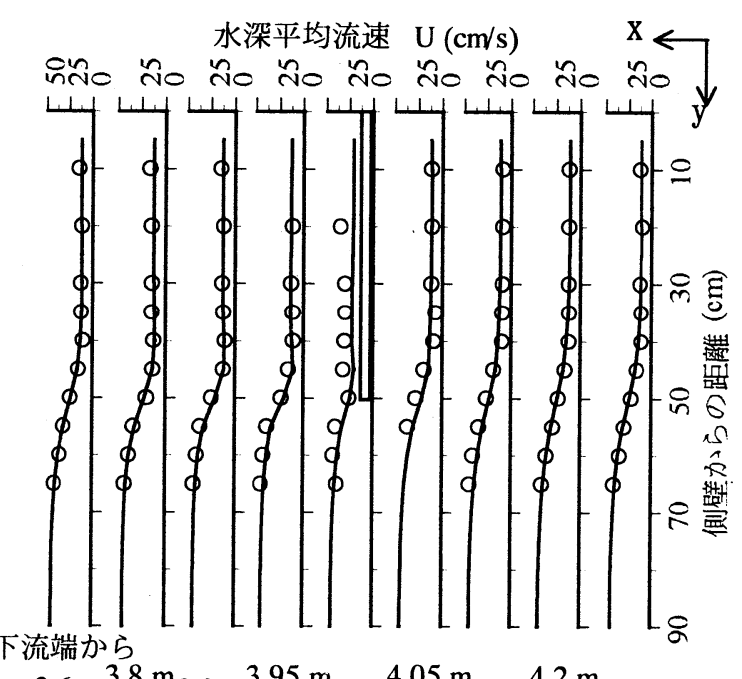

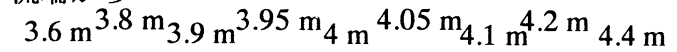

図-3-b 直角水制周辺の主流速分布の横断変化

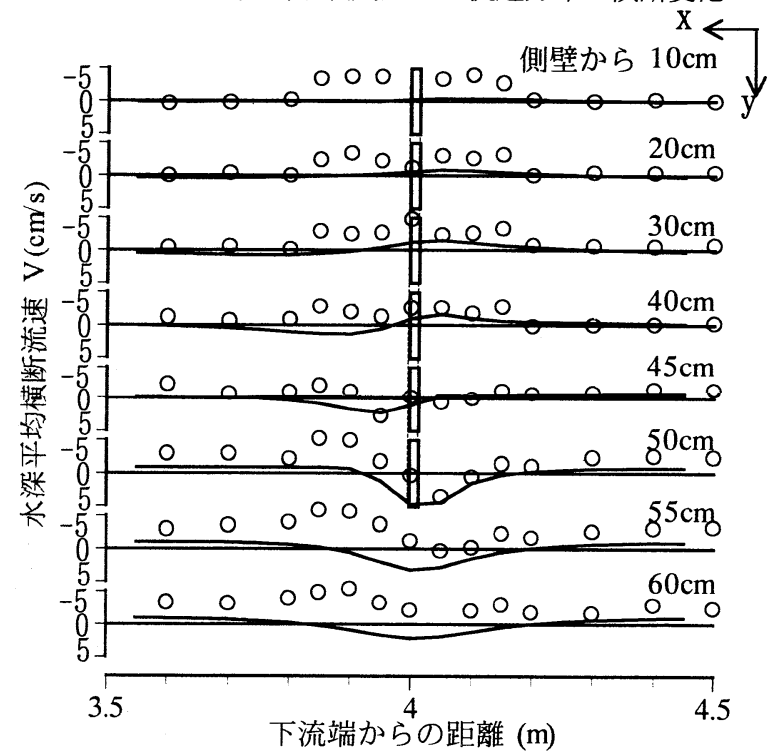

図-3-C 直角水制周辺の横断流速分布の縦断変化

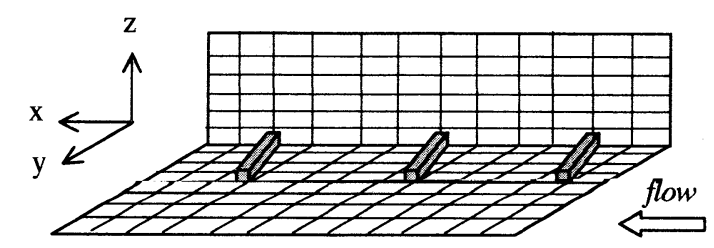

口水制設置位置 $\bigcirc \exp$. cal.

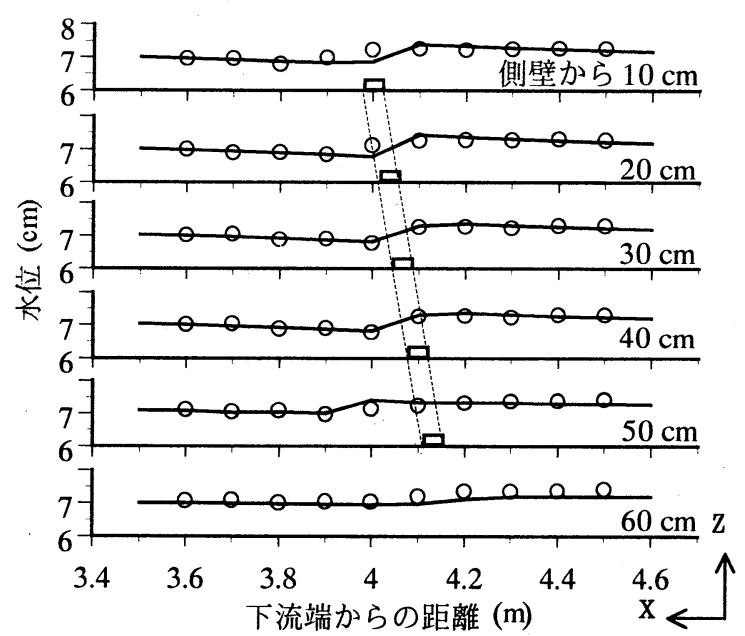

図-4-a 上流向き水制周辺の水位分布の縦断変化

水深平均流速 $\mathrm{U}(\mathrm{cm} / \mathrm{s}) \quad \mathrm{x} \leftarrow$

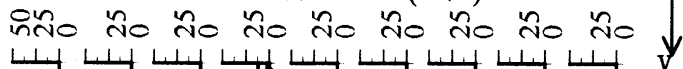

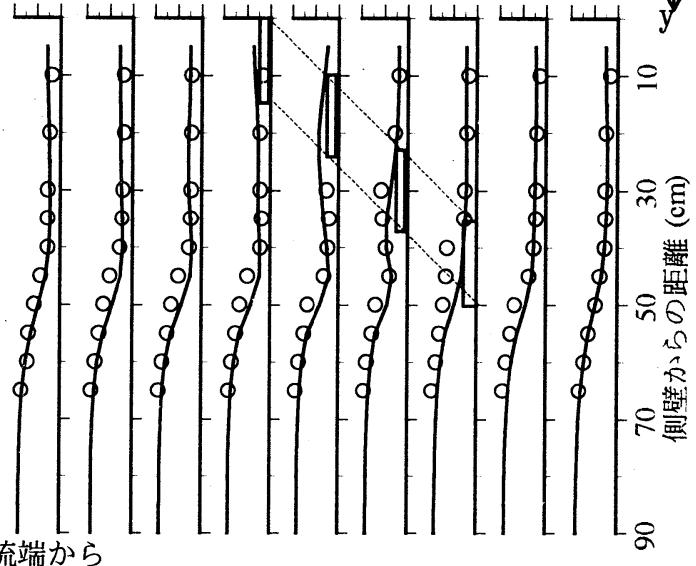

下流端から

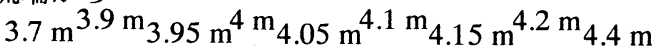

図-4-b 上流向き水制周辺の主流速分布の横断変化

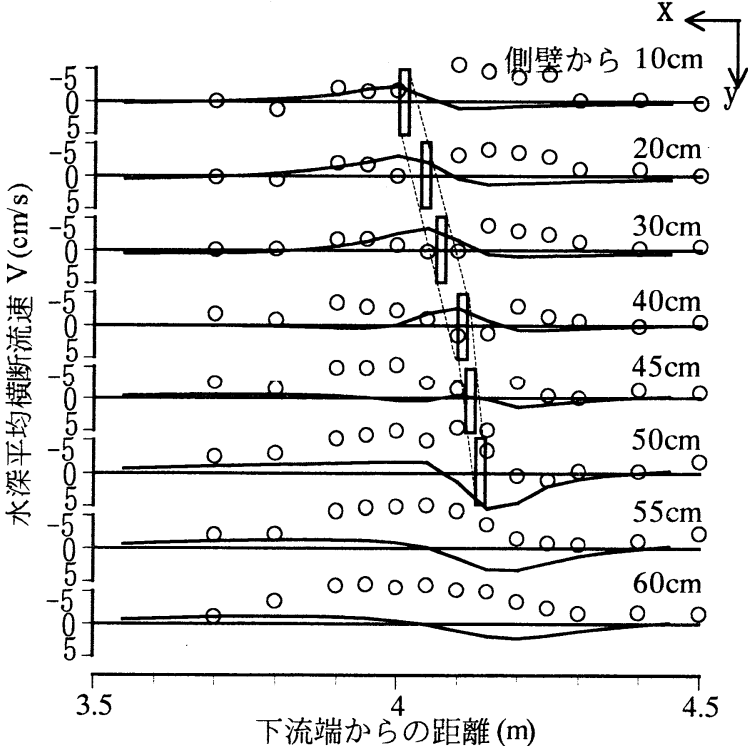

図-4-c 上流向き水制周辺の横断流速分布の縦断変化 


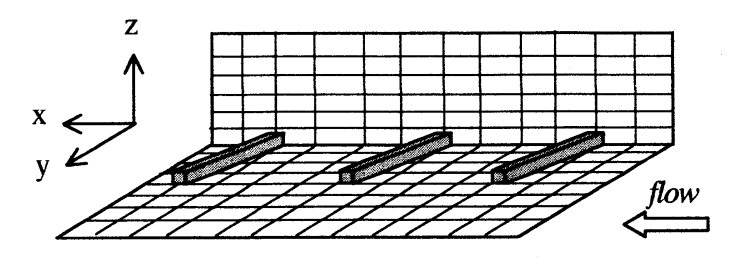

口水制設置位置 $\circ$ exp. - cal.

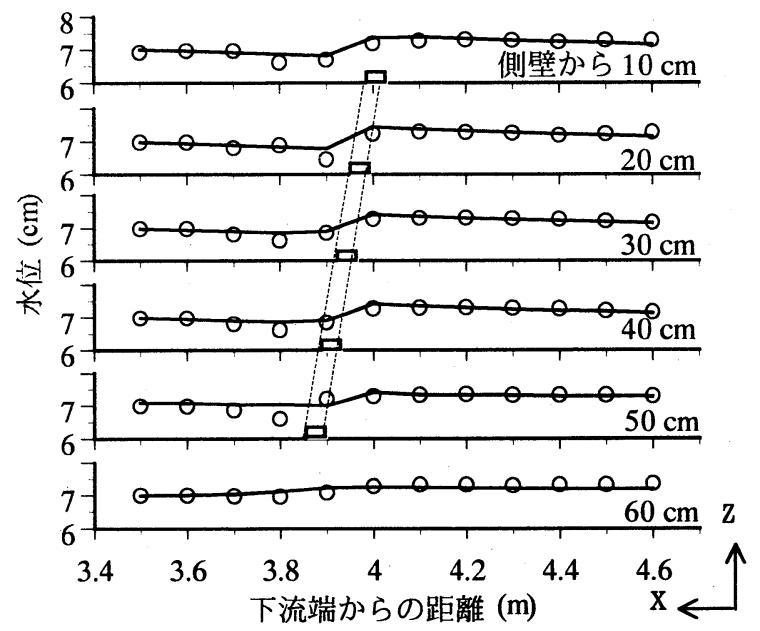

図-5-a 下流向き水制周辺の水位分布の縦断変化

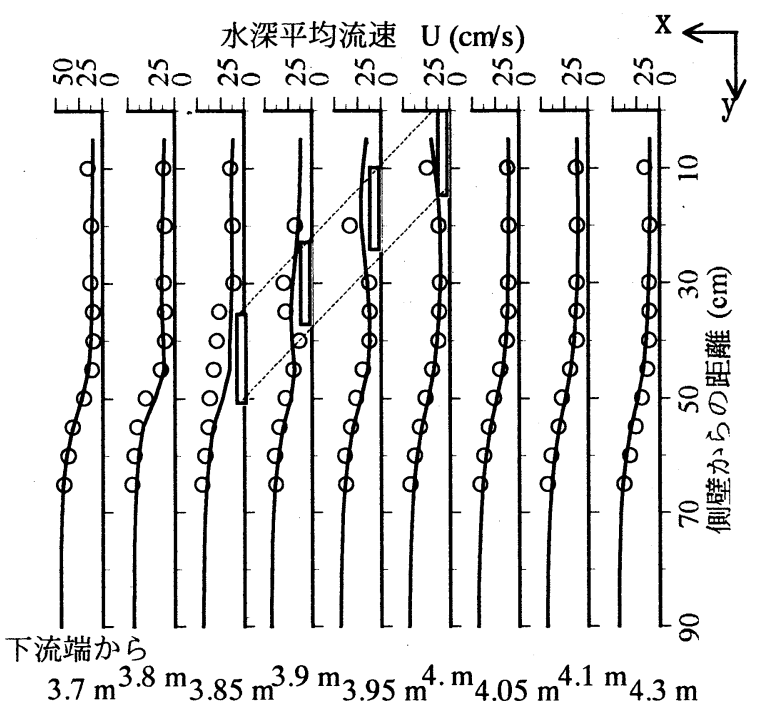

図-5-b 下流向き水制周辺の主流速分布の横断変化

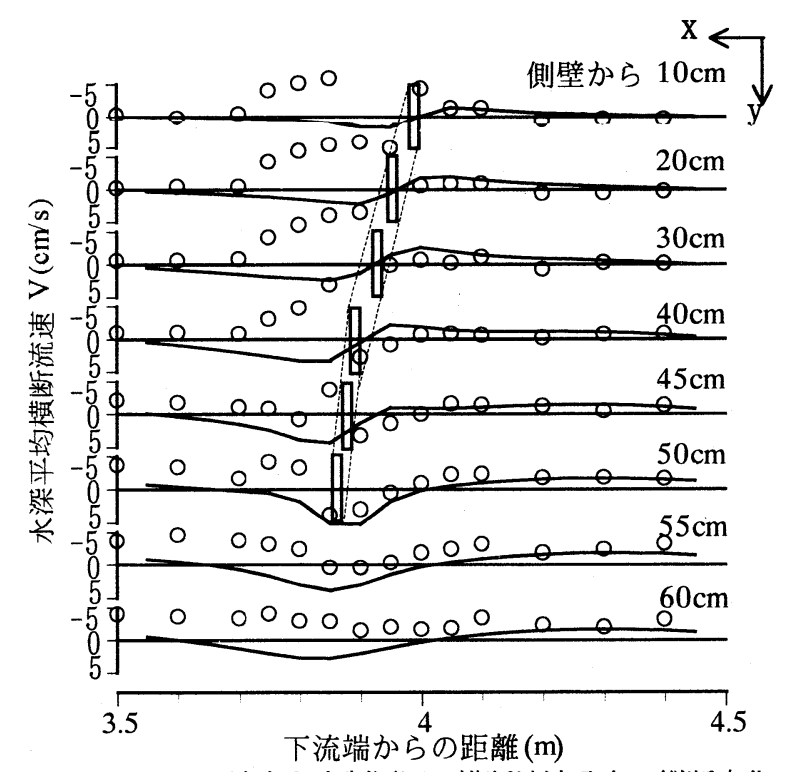

図-5-c 下流向き水制周辺の横断流速分布の縦断変化

\section{（1）水位分布}

図-3-a，4-a，5-aは，それぞれ直角，上流向き，下流 向き水制周辺の水位の計算結果と実験結果を比較したも のである. 水位は側壁付近の $10 \mathrm{~cm}$ から水制先端付近の 60cmまでの縦断分布を並べて示している. 3ケースとも 計算結果は, 水制からの外力による水位の堰上げ量, 全 体的な水面分布の特徵を再現することができている.

図-3-aの直角水制の場合，水制上から水制背後までの 側壁から水制先端にかけて, 計算水位はほぼ一様に実験 水位より大きくなっている。これは, 静水圧分布により 水位を計算したためであり，水制上を越流する鉛直面内 の剥離流れにより水制背後の圧力は静水圧分布より低下 しているためと考えられる.

図-4-aの上流向き水制の場合，水制上から水制背後ま での計算水位は直角水制の場合と異なり，実験水位の縦 断分布をよく説明している.これは, 上流向き水制では 鉛直面内の剥離流れによる圧力低下が小さいことを意味 している.

図-5-aの下流向きの場合，水制上の計算水位は直角水 制ほど実験水位より大きくはならないが，水制背後では 計算水位が実験水位より大きくなる．これは，直角水制 と同様に，水制上を越流する鉛直面内の剥離流れにより 水制背後の圧力は静水圧より低下しているためと, 後に 述べる水制背後での水制先端から水制域への流れ込みに よる平面的な剥離流れによる静水圧からの圧力が低下し ているためと考えられる.

\section{（2）主流速分布}

図-3-b，4-b，5-bは，水制周辺の主流速の水深平均值 Uの計算結果と実験結果を比較したものである.流れの 平衡区間における水制と水制の間のひと区間，下流端か ら3.6mから4.4mまでの各断面での主流速の変化が示され ている.3ケースとも主流速Uの計算結果は水制近傍を 除いて, 実験での水制域の減速を十分に再現することが できている。

図-3-bの直角水制の場合，水制上では側壁から水制先 端まで，計算值は実験值より小さくなっている．これは， 水制上の計算水位が実験水位より大きいことと, 縦断圧 力勾配が実験結果より小さく計算されたことに対応して いる.

図-4-bの上流向き水制の場合，水制先端付近を除いて， 水制上の縮流による流速増加を概ね表すことができてい る. 水制先端での計算の主流速Uは実験より大きくなっ ており, 上流向き水制背後の先端付近で圧力が静水圧よ り低下していることが考えられる。

図-5-bの下向き水制の場合，水制上の縮流による流速 増加は実験よりやや小さく計算されている。これは，直 角水制と同様に水制背後の計算水位が実験結果より大き く, 圧力勾配が実験結果より緩く計算されたためである. 
（3） 横断流速分布

図-3-c，4-c，5-cは，水制周辺の横断流速の水深平均 值Vの計算結果と実験結果を比較したものである. 水位 は側壁付近の $10 \mathrm{~cm}$ から水制先端付近の $60 \mathrm{~cm}$ までの縦断 分布を並べて示している.3ケースとも水制近傍を除い て水深平均横断流速 $\mathrm{V}$ 計算結果はおおむ水実験結果を 説明している. 水制近くの横断流速Vの計算結果は水位, 主流速に比べて実験值との適合性が劣っている.

図-3-cの直角水制の場合，実験での水制先端の水は水 の特徵をおおむね再現している，しかし，水制先端から 水制域に向かう流れは表すことができない。これは，圧 力の横断方向勾配が静水圧近似により実験より小さく計 算されたためである。

図-4-cの上流向き水制の場合，水制先端付近では水制 先端から水制域への流れが実験より小さく計算され，実 験值を十分に表現することができない，上流向き水制背 後の剥離域は主に水制先端から水制域一流れ込む平面的 な剥離流れからなり，水制背後の圧力低下は水制先端付 近で大きいと考えられる.

図-5-cの下流向き水制の場合，実験での水制先端の水 はねの特徵をおおむね再現している. 水制先端付近では 横断流速Vの計算結果は実験の横断流速分布の特徵を再 現している. 水制上から背後にかけて，実験では側壁に 向かう流れがみられる.この水制背後の流れと計算の横 断流速の結果は逆になる. 下流向き水制背後の剥離域は, 水制先端から水制域一流れ込む平面的な剥離流れと水制 上を越流する鉛直面内の剥離流れがともに強く，水制背 後での圧力は静水圧分布と異なっている.

水制周辺の流れの2次元解析において，3次元的な水制 水制周辺の流れに伴う圧力分布を考慮することは，主に 流体力を決める抗力係数や揚力係数の分布を考えること を意味する．そのためには，水制周辺の圧力場や乱流構 造を解ける水制周辺の流れの3次元解析結果を考慮する 必要があり, 今後の課題である.

\section{4. 結論}

越流型水制周辺の流れの2次元解析結果と実験結果の 比較から, 水制背後の剥離流れと圧力場を議論し，2次 元解析の適用可能性を検討した. 主要な結論は以下の通
りである。

（1）直角水制背後の剥離域は主に水制上を越流する鉛 直面内の剥離流れからなり，水制背後の圧力は静 水圧より低下している.

（2）上流向き水制背後の剥離域は主に水制先端から水 制域へ流れ込む平面的な剥離流れからなり，水制 背後の圧力低下は主に水制先端付近で起こってい る.

（3）下流向き水制背後の剥離域は，水制先端から水制 域へ流れ込む平面的な剥離流れと水制上を越流す る鉛直面内の剥離流れがともに強い。

\section{参考文献}

1)秋草勲・吉川秀夫・坂上義次郎・芦田和男·土屋昭彦:水制 に関する研究,土木研究所報告,第107号, 1960 .

2) 福岡捷二・高橋晃·渡辺明英: 水制工の配置と洗掘防止効果に 関する研究,土木研究所資料,第2640号, 1988 .

3) 福岡捷二・渡辺明英・西村達也: 水制工の配置法の研究, 土木 学会論文集, No.443, II-18, pp.27-36, 1992.

4) 山本晃一 : 日本の水制, 山海堂, 1996.

5) 福岡捷二・西村達也·高橋晃・川口昭人・岡信昌利 : 越流型水制 工の設計法の研究, 土木学会論文集, No.593，II-43，pp.51$68,1998$.

6) 福岡捷二・阿部友則·西村達也:信濃川小千谷越路地区の河床 変動対策一現地観測, 模型実験, 数值解析結果の比較一,水工 学論文集,第44巻,pp.347-352, 2000.

7) 福岡捷二・西村達也・岡信昌利・川口広司: 越流型水制周辺の流 れと河床変動,水工学論文集, 第42巻,pp.997-1002,1998.

8) 福岡捷二・渡辺明英:ベーン工の設置された湾曲部の流れと河 床形状の解析, 土木学会論文集, No.447, II-19,pp.45-54, 1992.

9) 川口広司・岡信昌利・福岡捷二 : 越流型水制群に作用する流体 力の特性,水工学論文集,第44巻, pp. 1065-1070,2000.

10)福岡捷二・渡辺明英.川口広司・安竹悠: 透過水制工が設置さ れた直線流路における流れと河床変動, 水工学論文集,第44 巻, pp.1047-1052,2000.

11)河原能久・彭静·藤井和久:越流型水制工を有する河道内の流 れの3次元数值解析, 第3回河道の水理と河川環境に関するシ ンポジウム, pp.17-22, 1997.

12)崇田徳彦·清水康行:Reynolds応力を考虑した水制を含む流 れの計算,水工学論文集,第37巻,pp.487-494, 1992.

(2000.10.2受付) 